\title{
YOUNG PEOPLE'S JOINT LEISURE ACTIVITIES IN TRADITIONAL KARELIAN CULTURE: NORMS AND SOCIAL PRACTICE
}

\author{
VALENTINA MIRONOVA \\ Candidate of Philological Sciences, Senior Research Associate \\ Folklore Section and Audio Archive \\ of the Institute of Linguistics, Literature and History \\ Karelian Research Centre, Russian Academy of Sciences \\ Pushkinskaya Street 11, Petrozavodsk \\ 185910, Karelia, Russia \\ e-mail: tutkija@mail.ru \\ JULIA LITVIN \\ Candidate of Historical Sciences, Junior Research Associate \\ Ethnology Section of the Institute of Linguistics, Literature and History \\ Karelian Research Centre, Russian Academy of Sciences \\ Pushkinskaya Street 11, Petrozavodsk \\ 185910, Karelia, Russia \\ e-mail: litvinjulia@yandex.ru
}

\begin{abstract}
The paper* considers common youth leisure activities in traditional Karelian culture, from the point of view both of the culturally prescribed norms and the actual behaviour. Special attention is paid to official and social adolescent development frameworks and to reflection of these age-related stages in folk vocabulary. The paper uses a large number of recently published and unpublished ethnographic and folkloristic sources. The authors come to the conclusion that in Karelian culture there is a specific age-group framework for adolescence, as well as gender-related differences between male and female behavioural patterns. The paper shows that girls had to undertake more varied tasks than boys as, on the one hand, they were to play socially prescribed roles and follow moral obligations, remaining modest and, on the other hand, had to be active in order to get married and give birth to children.
\end{abstract}

KEYWORDS: youth leisure • socio-cultural history of Russia • traditional Karelian culture

* The article was prepared within the framework of two government funding projects - Folklore Traditions and Booklore of the European North: Sources of Study, Textology, Poetics, Ethnographic Context (no. 0225-2018-0013), and The Peoples of Karelia: Ethnic and Local Traditions in Historical Dynamics (no. 0225-2018-0017). 


\section{N T RODUCTION}

Leisure activities play a significant role in young people's lives as it is during adolescence that many lifestyle habits are formed and, not infrequently, their future socio-cultural status is founded. The concept of leisure activities depends on the epoch, includes ethnical and national features within social groups.

The paper aims to describe traditions in the joint leisure activities of young people in traditional Karelian culture in the second half of the 19th and early 20th centuries. The mechanism of cultural socialisation becomes most visible in initiation rituals, which set a conditional border between age periods. Northern European peoples did not have rituals similar to those in Africa. Initiation rituals (for example girls' spring rituals) were organised to show the transition to a new age status, although it was not looked upon as a separate ceremony (Bernshtam 1988; Bayburin 1993: 60). Meanwhile, the adolescent development stage was traditionally restricted by specific social norms, different for girls and boys, with local variations across the territory of Karelia. Investigation into this subject allowed us to systematise youth leisure activities through an account of social seasonal leisure traditions, understand cultural and gender socialisation, and acquire deeper knowledge of the local ethnic history and traditional culture.

We do not make unjustified conclusions and agree with Lila Abu-Lughod's (1991) principle of the "ethnography of the particular", in which she postulates the presence of various traditions within local cultures. Youth customs and mantic practices (for example fortune telling) have been left out of the scope of the paper as they might become the subject matter for independent investigation.

\section{HISTORIOGRAPHIC REFERENCE AND SOURCES}

Russian rural leisure time is widely represented in the ethnographic literature devoted to the study of social life and rural cultural traditions. Publications by Ivan Snegiryov, Alexandr Tereshchenko, Dmitry Zelenin, Petr Efimenko made in the 19th and early 20th centuries deserve special mention. They describe the rural leisure activities of the Russian population of all age-groups on the basis of the evidence collected. In the 20th century, Vladimir Chicherov, Vladimir Propp, Vera Sokolova and Tatyana Bernshtam studied rural leisure pastime in the context of local public opinion. The study by Bernshtam (1988) deserves special mention as it reports on the place and role of young people and defines their functions in household labour and ritual spheres of life in prerevolutionary rural Russia.

Some Karelian ethnographers who studied adolescent leisure pastimes in connection with the lifecycle customs of rural communities considered them to be the first phase of wedding ceremonies (Surkhasko 1977; Ivanova and Mironova 2014; A. Konkka 2015). Material gathered among the Livvi-Karelian population coincide with some examples from the Vepsian data due to their mutual cross-cultural influence (Vinokurova 1994). Publications by Finnish ethnographers describing earlier empirical evidence are thought to be of considerable importance for the present investigation (Virtaranta 1958; 1964; Koponen et al. 1983; Joki and Jeskanen 1993). The complex study by Matti Sarmela (1989), devoted to Finnish folklore, with accounts of linguistic, ethnographic and folk- 
loristic sources, is of special value. Our paper also considers the gender approach used in publications by Finnish folklorists who studied bodily and cultural aspects of sexuality and the female magical power (väki) of lempi (Apo 1998; Stark 1998; Keinänen 2003).

Studies by historians on Karelian youth socialisation mainly consider marriage age, peculiarities of wedding markets and inter-confessional marriage (Hämynen 1993; Smirnova 2002; Chernyakova 2003; Shikalov 2010; 2013). Olga Ilyukha (2007) has reconstructed childhood in the Karelian villages. This interdisciplinary study uses historical, ethnographic and anthropological data, and contains valuable material concerning people's descriptions of childhood and adolescence.

According to the purpose of the study, the sources have been divided into three wide-ranging categories: legal documents, ethnographic and folkloristic sources, and linguistic data. The first category includes the official legislative acts that regulated the legal capacity of young people in the Russian Empire, as well as the rules of common law for Karelians, which prescribed a wider scope and variation of rules.

Ethnographic and folkloristic records present the second group and describe some of the leisure activities of young people. These were recorded by Russian and Finnish ethnographers in the second half of the 19th and early 20th centuries and were published either as separate volumes or as articles in local Karelian periodicals. This group also includes field materials gathered by researchers from the Institute of Linguistics, Literature and History during expeditions to various Karelian regions in the first half of the 20th century. These materials can be found in the Scientific Archives of the Karelian Research Centre, RAS (further, SA KaRC). The materials are of special value as they contain complex evidence concerning history, culture and everyday life in the Karelian population. Recordings of the field trips remained unstudied by researchers for a long time as they had not been systematised.

Linguistic data are included in the third group, represented by Karelian dictionaries (Koponen et al. 1983; Makarov 1990; Joki and Jeskanen 1993; Fedotova 2000) and by a specific kind of source - samples of Karelian dialects. Samples were collected to study the primary Karelian language. However, they contain other linguistic data, and ethnographic and folkloristic recordings, because of the wide range of topics that were touched upon during the open interviews.

The materials are organised diachronically and reveal transformations in patterns of youth social activities. The groups of sources above were interpreted using textual analysis and the method of complex examination of folklore. The latter combines different types of source, and data from various fields of the humanities, in order to study folkloric plots, motifs and images. While analysing folklore related sources relevant to this study, linguistic and ethnographic data were also applied. Neonila Artemovna Krinichnaya's (2014) scholarly works devoted to Russian mythology were written in the same vein. Including the categories of ethnos, gender, age and status in the analysis allowed us to improve our understanding of Karelian youth community, study norms and prescriptions, as well as identifying variations thereof. 
Before 1917 Karelia did not exist on the administrative and territorial map of Russia. In the 19th and early 20th centuries, this name was informally applied to areas mainly inhabited by the Karelian population. Karelia is traditionally divided into three ethnocultural zones: Southern, Middle, and Northern Karelia. The first ethno-cultural zone was formed in close contact with Russian and Vepsian cultures; Southern Karelians (ethnic sub-groups livvi, livgilaizet 'Karelians-Livviks' and lyydi, lüüdi 'Karelians-Ludiks') lived in Olonets and Petrosavodsk Uezds (counties); Northern Karelian culture (the territory known as Vienan Karjala in Finland and as Belomorskaya Karelia in Russian) was influenced by the Sami and Pomors. Northern Karelians (ethnic sub-group karjalaižet 'Karelians proper') populated the western part of Kem' Uezd of Archangelsk Gubernia (region). The territory of Central Karelia which included the north-western part of Povenets Uezd of Olonets Gubernia served as a transitional zone between Northern and Southern Karelia.

A unique historical, cultural and religion landscape with its specific norms and standards of behaviour is thought to be formed due to administrative and territorial isolation and the variety of environmental and climatic conditions in Karelia, as well as the contact zones between ethnic groups. Meanwhile, Karelia was part of the Russian Empire and formally had to observe its laws and regulations. The official legislation and rules of common law of the time make it possible to define the scope of 'young' and to determine the matching degree of law to local variants within Karelian culture.

\section{THE FRAME OF ADOLESCENT DEVELOPMENT}

Russian law in the late 19th century (1870-1899) stated that individuals younger than 21 were considered children: they were called maloletniye, 'young children', until they were 17, and between 17 and 21 they were called nesovershennoletniye, 'minor children' (Kantorovich 1899: 1). Transition from one stage to the next was accompanied by increased legal capacity. As a whole, Russian legislation differentiated the property rights of parents and children (just as with the property rights of spouses). Thus, parental authority over a child ceased when the parents died or were deprived of possession. Personal parental authority over a daughter ended when she got married. Parental authority over son became limited after his separation from the family.

The study of the childhood frameworks by Ilyukha (2007: 52-53) illustrates inconsistency in the law. In a Karelian village, for example, the growth of the second teeth was looked upon as one of the markers of a child beginning adolescence. The older age limit of childhood was not clearly defined and had quite a number of local variations, within the age range of 13-16. In Karelian culture socialisation of children younger than 5-7 years (livv. ilonaigu 'fun game stage') generally occurred through games, folklore, and communication with parents, grandparents and contemporaries with the purpose of learning family and social traditions and norms. During the 'fun game stage', children probably unconsciously copied the patterns of adult activities, while 5-6-year-olds were trained purposefully, directly and systematically to play 'male' and 'female' social roles (Pushkareva 2003: 15). 
Children of 7 and 8 years were taught to be responsible for their behaviour. When they reached the age of 15, new elements were added to their clothes. Younger children wore only long printed cotton and canvas shirts (in the summer). Seven-year-old boys tied their shirts round the waist with a belt. In wealthier families, the 7-year-olds began wearing high boots, waistcoat and neckerchief. Having ploughed the field, an adolescent boy could change his pair of white shorts for dyed trousers. The girls' clothing of that time had a more complicated, bright, trim. In joint games, children were united by gender (Ilyukha 2007: 52). However, 7-8-year-old children did not form a separate social group, as they were closely connected with the family. This is reflected in the folk lexis. Boys were called poika (K.p.), brihaččuine (Livv.), poige (Lud.), which denoted 'boy' or 'son'. Girls were called tyttö ‘a girl', 'daughter', or neižlapsi (Livv.), literally, a 'female child'. Girls' childhoods were usually shorter than the boys' as they were involved in household chores and care for their siblings sooner. Girls were prepared for maternity from an early age.

Official legal norms stipulated that it was at the age of 21 that both males and females acquired full legal capacity. In the Karelian folk tradition, a 16-year-old boy or girl might be considered täyšivartini, 'full-grown', i.e. a person who enjoyed full social capacity (ibid.: 42). Sometimes, 13-14-year-old young adolescents, mainly girls, could also join this category.

The girls were allowed to participate in youth festivities from the age of 13 , but for peasant girls only if they suited some informal criteria such as being strapping or active, or otherwise if they belonged to a well-to-do family (Surkhasko 1977: 43). It should be noted that Finnish and Veps young people at about the same age, 13-16 years old, started to form a separate social group: they jointly spent more time at entertainment and birthday parties, danced, participated in swing games and made bonfires. Moreover, boys and girls went jointly to church, to fairs, and to weddings organised in nearby villages (Sarmela 1989: 250; Vinokurova 1994: 62).

Local groups of Karelians defined the male and female adolescents who joined the older social group differently. Thus, unmarried males were called priha (K.p.), briha (Livv.), or brihač (Lud.). Moreover, the term briha was further used to define a young man after he was married, until his wife gave birth to a son. The word tyttö continued to be used for girls, but more often they were addressed as neičyt (K.p.), neidine (Livv.), neid, neičud (Lud.) - 'a maiden'. They were talked about in typical fashion: on neikoidu talois vai olis sulhasi vastah ('there are maidens in the house, if only there were suitable grooms for them') (Koponen et al. 1983: 466).

The onset of menstruation was probably considered the age for a girl to obtain the status of 'girl of marriageable age'. Yuriy Shikalov (2013: 93) studied the aspect of young female's marriageable age in the Belomorskaya Karelia region and concluded that northern female Karelians and Sami reached puberty at the age of 15. Jussi Lukkarinen (1933: 162) obtained similar data: the age of menarche depended on the habitat, ethnicity and socio-economic conditions (including diet). Precise statistics are not available due to the fact that the subject under discussion was taboo in peasant culture. Physiological changes found their reflection in clothing symbolism: with the onset of menstruation, the girl was to wear an apron with pockets showing her ability to bear children (Keinänen 2003: 74). 
Male and female adolescents participated in traditional rural festivities and specific youth fun activities connected with their transitional phase. Bes'odu (Livv., K.p. < Rus. беседa 'conversation', 'chat'), illačut, illaništujašet, iltakisat, iltatanssit (K.p.) - referred to below as besyodas - 'evening gatherings and dancing' indoors and open-air strolls were common leisure activities. It could be said that besyoda, as viewed today, became popular with Karelians at the same time as the quick assimilation of the lyric song tradition (Russian and Finnish), i.e. approximately from the first half to the mid-19th century. Before that, Karelians organised working day, or so-called 'spinning' get-togethers and päyvykečoi, literally 'day time get-togethers'. Participating in such kinds of amusement was an important phase marking the transition of the adolescent to a new status, that of marriageable girl or bachelor. It should be noted that these were different stages within one age period.

Vivid characteristics of the unmarried period of neisaika (K.p.), neizaigu (Livv.) for girls and prihassusaika (K.p.), or brihastanduaigaine (Livv.) for young men are reflected in quite a number of folklore texts. Thus, in Karelian joiku, ${ }^{1}$ which are performed during wedding ceremonies, the time of courtship (the unmarried period) is represented as kultani aika, 'golden age', laatnoini lauluaika 'pleasant singing time', šoma šulhaissušaika 'wonderful courtship period', katrilliaika 'quadrille time', etc. Girlhood is most colourfully described in wedding laments: nuorukkaiset iloaikaiseni 'young girl's times of joy' or nuorukkaiset vuakloaikaiseni 'young girl's short times', ihalmot igäizet 'wonderful years', iz'umnoit igäzet 'sweet raisin years', kaunehet igäzet 'beautiful years', etc. (Lavonen et al. 1993: 220-221; Stepanova 2004: 79). The use of these epithets during wedding ceremonies was symbolic: they described the different positions of youth before and after marriage. The 'time of joy' and the 'wonderful years' gave way to hard labour. Indeed, this was the period of common practice when young people were released from some household chores and were supposed to participate in youth festivities and amusements to follow the traditional norms. Older people kept a watchful eye on the fulfilment of such customs (Konkka and Konkka 1980: 99).

The leisure structure included both joint pastime and separate male and female activities, for example päivükečoi (women's gatherings) where girls and married peasant women did their needlework. The objective of the current study is to investigate only joint gatherings as their analysis may reveal special young male and female behavioural patterns through the prism of norms and social practice.

Karelian tradition defines besyoda as a youth social gathering, commonly held indoors. Such get-togethers were year round events, regardless of the season. Traditional winter gatherings started after the end of autumn work in the fields (Blagoveshchenskiy 1876: 135). More commonly, however, they started after the Orthodox Pokrov holiday (the Feast of the Intercession of the Theotokos) and lasted until Maslenitsa. ${ }^{2}$ Adolescents could gather for besyoda every day but Saturday, or three times a week, on Tuesday, Thursday and Sunday (SA KarRC Fond 1, inventory 50, file 1, p. 26; Konkka and Konkka 1980: 123). The days for gatherings were chosen following the Orthodox Calendar according to which some days were banned for joyful activities for religious reasons. 
In winter, male and female adolescents gathered in a log house (mainly at the house of a single old person), village barn, or bathhouse. Girls were responsible for finding and renting a room for the gathering, while the boys' duty was to pay for it (Georgievskiy 1890: 733). In the early 20th century, there was a fixed room rent of 5 kopeks per bachelor, in a large village Prokkoilu (Prokkoyla) of Syamozero Volost' (District). At the same time, the price depended on the connections of a village with the town (for example, some villages in Southern Karelia), and on the prestige of the seat location in the house. For example, seats below the iconostasis were most expensive, costing 1 rouble; seats in the middle of the bench cost 50 kopeks and the cheapest seats were closer to the door (Nikolskiy 1906: 3; Surkhasko 1977: 50). These examples illustrate the establishment of monetary relations in the peasant community, including young people.

Regardless of the method of payment, girls were responsible for arranging the room and maintaining order in the house. This related to different ways in which communities of girls and boys were localised. Girls' space was more often in the home, or in summer outside on a hill, or in a meadow where swings were set up or where they sang and danced in a circle. Young men strolled, or, as they said, wandered along the streets, went to visit other villages. The girls' space was stationary, while the boys' space was mobile (Shchepanskaya and Shangina 2005: 13).

For weekday get-togethers, Karelian girls came with their spinning wheels, but for holiday gatherings they left their needlework at home (Georgievskiy 1890: 743). In remote villages, the tradition remained unchanged until the 1960s. It should be noted that in villages located closer to cities and trade routes, the tradition of coming to gatherings with handiwork had already been lost by the early 20th century.

Girls asked their parents' permission to go to festive besyoda. Karelians-Ludiks recalled: "In the old days, we were not allowed to go to the besyoda: 'Father, mother will you allow me to go to the holiday, or not?' Father/mother answer: 'Go with God. Know how to behave yourself in public."' (Virtaranta 1964: 39) This practice was the result of patriarchal traditions, which implied the responsibility of the family for the girl's honour and reputation. The phrase "know how to behave yourself in public" uttered by the parents of a rural peasant girl reminded her that she should behave well and not lose face even during joyful games. The example illustrates the role of prearranged communicative practices in the upbringing and training of young girls, who were in this way encouraged to follow the traditions and behavioural prescriptions of the peasant community. Such prescriptions for boys have not been found in folklore collections.

A gathering of young people in spring and summer had its own name, kisa, kiža, which can be translated as 'dances', 'games' or 'summer besyoda'. The similarity of these terms can be explained by the fact that initially the numerous youth games laid the basis for Karelian besyoda. The most common games among Karelian youth were puaroil istundu ('sitting in a pair') and pitkykiža ('long game'). Later on, dances and songs came to dominate the leisure structure. These games were aimed at choosing a partner and further joint communication activities. In Russian society, the terms igra 'play' and igrat' 'to play' defined the youth lifestyle and behaviour in practically all everyday and sacral situations, as well as in joint labour and associated amusement practices (in the field or forest, or at gatherings). Singing was also defined as igra, mainly of the young people, with acting out: pet' igraya 'to sing by playing', igrat' po pesne 'to play according 
to the song' (Bernshtam 1988: 11). The existence of similar terms shows the typological similarity of this phenomenon in neighbouring peoples, in this case Russians, Pomors, Veps and Finns.

A contemporary of such events in late 19th century described this Karelian tradition as follows:

Young maidens dressed in their best clothes walk in pairs, hand in hand, in a long line. Gradually, young males join their line, and then maiden's pairs become split. [...] The best of them, most fashionably dressed and wealthy, head the line. Then, there go poorer and poorer pairs. The most miserable conclude the line. In the course of the event, the girls leave the line several times to change their clothes, so that some of them have to change as many as six or more times during the evening. (Minorskiy 1879: 732)

This may suggest that the wealth and welfare of the parental family played a great role in defining young female and male peasant status and allowed the 'best' girls and boys to be leaders of the youth community.

\section{THE BEHAVIOUR OF YOUNG PEOPLE: NORMS AND SOCIAL PRACTICES}

The norms of joint youth leisure behaviour depended on the time of gathering (weekday and festive get-togethers, open air festivities), also on local ethnic tradition, and had gender variations. Weekday get-togethers were, as a rule, modest, and rarely visited by boys. As reported by Karelians from Seesjärvi (Segozero), boys came "with idle hands", i.e. without work, sat close to their favourite girls and chatted: "And a lad who likes a girl is sitting close to her spinning wheel, guarding, talking" (SA KarRC Fond 1 , collection 5, file 265, p. 5). Sometimes a boy sought to distract a girl from handicraft. Thus he did not only show his interest in the girl, but also observed whether she was skilful at work. ${ }^{3}$ Judging by the recordings from Southern Karelia, young female and male adolescents were to sit in different corners of the room: "Open meetings and besyoda on weekdays were considered to be indecent and compromised the girl's dignity" (SA KarRC Fond 1, inventory 50, file 3, p. 20; Bogdanov 1930: 37).

Festive besyoda were different. Southern Karelians told ethnographers that the appearance of young men changed the girls' behaviour: "[T]hey expressed their joy, became spirited and cheery". Some would sit together "as a pair, close to each other", and "hugged and kissed each other" (SA KarRC Fond 1, inventory 50, file 4, p. 18; ibid.: file 5, p. 44; Virtaranta 1964: 31). Young people sitting next to each other was looked upon as the heart of the gathering, the quintessence of the besyoda. A young man could openly kiss his lass and hug her in all possible ways. During breaks between games, a girl would sit on her boy's lap, and he kissed and fondled her. Moreover, if a pair did not follow this kind of behaviour, they were laughed at (Lukkarinen 1933: 82).

Mikhail Georgievskiy (1890: 743), a teacher in the village of Pühäd'ärvi (Svyatozero) in Southern Karelia, wrote: "[D]uring besyoda the youth are in their small world: here they have freedom of speech, there are no constraints, so they can freely express themselves". Meanwhile, it should be said that there were local variations in the traditions 
of Karelian youth behaviour. Thus, in Pomorye and in Belomorskaya Karelia, relatives came to keep a watchful eye on games and manners, especially of girls. Finnish ethnographer Into Konrad Inha (1911: 134-136) reported in 1894 that during dances, men, married women and the elderly climbed up onto the seni (a small area between the porch and a living space in a log house) partition, observing and gossiping. Such considerable differences in behavioural patterns can be explained by the impact of the Old Believers in Northern and Middle Karelia as these strict canons also affected youth gatherings. In villages with strong Old Believer ${ }^{4}$ traditions, youth gatherings were also noted by restrained behaviour and were under close supervision of elder women (Bernshtam 1988).

In addition to local variants reported above, there were also gender differences in young male and female behaviour. Thus, during festivities, young male adolescents were to show such features as boldness, masculinity, physical force. It is interesting to note that there was an unspoken division of young people into 'ours' and 'outsiders' as young people from nearby villages came to participate in festive besyoda and open-air amusements. Some young men were noted to show 'group bravery' during festivities. Young males from the village that organised the besyoda were looked upon as the hosts. Attack on their authority could provoke fighting. The old timers recollect: "Earlier, men would often fight" (Makarov 1990: 384). Such acts were a characteristic element of festive behaviour of young men as they proved their strength and boldness.

Young females, on the contrary, tried to keep their reputation and dignity, which is reflected in the Karelian proverbs: Ei ole besodas muidu gu minä iče da kuldaine kassu, 'there is nobody but me and my golden braid at the besyoda' (Miettinen and Leino 1971: 29). The braid served as a symbol of maidenhood, was the synonym of beauty and embodied the girl's honour, innocence and dignity. On the one hand, girls were supposed to stay modest and behave with dignity, while on the other hand feeling at ease to some extent. Or, put another way: public opinion and future marriage prohibitions demanded that a girl should stay modest and have good morals, while the behavioural norms of youth group games required liberty of action.

Apart from certain behavioural patterns in Karelian culture, there was also a set of rituals and magic actions for young girls to get married when the time came. The magic of increasing lempi in the period of maidenhood was of special importance. The study of expressions in the Karelian language and folklore as well as ethnographic evidence has shown that lempi was initially gender neutral, i.e. applied to both young girls and boys. Only from the late 19th century did the ritual to increase lempi narrow and started to be applied only to young girls. Following folk beliefs, a young peasant girl whom young men invited to play and dance possessed lempi (K.p.), lemmekäs (Livv.), lembekäz (Lud.). The notion denoted not only physical beauty and sexual appeal, but also a maiden's dignity and good name. There was a whole set of ways to increase lempi, described in detail in archival sources and publications (Surkhasko 1977; Stark 1998; Keinänen 2003; Konkka 2015: 276-288; Ivanova and Mironova 2014: 11-107). As a whole, there was cumulative ritual codes including spatio-temporal features (midnight - home, bath, slashed field), particular actions (taking a steam bath), objects (broom) and verbal magic (spells). Many of those codes were erotic in character, but were approved by the peasant community as they were leading the maiden to what had been traditionally predestined. 
The research indicates that young female and male adolescents behaved differently regarding the tasks they were to realise in the future. Young males were supposed to develop such qualities as boldness and strength as in future they were supposed to take responsibility for household economics. Young female behaviour was characterised by multitasking and increased variability within the framework of prescribed social norms. Socialisation with boys on weekdays in public was considered indecent and compromised the girl's dignity. Alongside with this, the unmarried girl could enjoy loose interpretation of the rules during festivities. The girl put on her best clothes, became active to attract the attention of as many boys as possible. In the village of Pühäd'ärvi, for instance, there was a notion that if another girl entered a room where another girl was getting ready for the besyoda, then that girl would not be invited to the dance (kadril'), which was thought of as a dishonour. Conversely, if a boy or a man entered a girl's room then the girl could hope that a boy would ask her for dance. Being lonely during the besyoda was considered humiliating and shameful (Georgiyevskiy 1888: 164; Blagoveshchenskiy 1878: 1135). These behavioural strategies adopted in the society were the symbolic capital of young people - the reputation not only of the young people, but also of whole rural communities.

\section{YOUTH GATHERINGS AS A WAY OF FINDING}

\section{A MARRIAGE PARTNER}

The main purpose during the premarital period was to find a worthy mate. A widely used Karelian proverb says: Vesillä venosen mieli, tytön mieli miehoillah, which can be translated as 'a boat needs water and a girl needs to get married' (Miettinen and Leino 1971: 569). Publications and archival sources describe some criteria for choosing a marriage partner, for example social position and wealth were considered essential, and to get married, the young female and male should be healthy for procreation. Complexion was also considered, especially the girl's appearance. The Karelian ideal of female beauty was as follows: strong but flexible constitution, briskness, a round face, big blue eyes, a rather small nose, thin lips, blond hair (Shikalov 2013: 94). However, diligence was appreciated above all: Sit on kačo neidine näbei, ruadau kui värtin vieröy, 'the girl is beautiful only when she works as the spindle twirls' (Miettinen and Leino 1971: 308). Overall, household economics was likely to play the most important role in marriage as it was looked upon as a certain economic act: accepting a new family member as a person to work and continue the family line.

'Older' young people who remained unmarried were grouped separately as spinsters and bachelors. Local Karelian groups had their own criteria of transition from the stage of unmarried girl to the stage of spinster. In Southern Karelia as of the late 19th and early 20th centuries, the girls usually married for the first time at the age of 21, while for young men the average age was 24; in Northern Karelia, the female and male average ages were 23 and 28 respectively. It was found that the further north a settlement was located the higher was the marital age. This can be explained by a whole set of socio-economic and cultural factors (Litvin 2013). Unmarried woman were called vanha tyttö, vanhu neičyt (K.p.) 'an old girl', neizakku (Livv.), literally 'a woman-girl', isänpenkin istuja (Livv.), literally 'the one sitting on the father's bench' (Makarov 1990: 224). 
In Northern Karelia, it was said of spinster's that kašša hartiella happanou, i.e. her 'braid would rot on her shoulder' (Fedotova 2000: 71). As was mentioned earlier, the braid was a symbol of maidenhood that would become 'rotten' or 'lose its power' if the girl was not married at a proper age. Thus, rural society gave names with negative connotations to the unmarried girls. This tradition survived into the 20th century.

What concerns unmarried young men, a smaller number of negative names was recorded. Such young men could be called vanha poika (K.p.) 'old boy', vahnu briha (Livv.) 'old chap', brihamies (Livv.) 'man-guy' or akatoi 'the one without wife'. The image of the man without a wife has been reflected in Karelian proverbs, for example Akatoi elos $k u$ kellotoi lehmy ('a man without a wife is like a cow without a bell'); Akatoi elos ku löylytöi kyly ('a man without a wife is like a bathhouse without steam'); Akatoi elos ku päčitöi perti ('a man without a wife is like a house without a stove') (Sinitskaya et al. 2007: 5). These examples show that a bachelor or a widow was compared with an object that lost its value and essence in the absence of the other object. Unmarried young men were a rare case in a traditional village. If a man remained unmarried for a long time, then this was considered the effect of evil forces, a curse or spoilage. A man's personal qualities were seldom taken into account when explaining his unmarried state (Prokopyeva 2005: 669).

Sanctions of the rural community were expressed not only in certain verbal forms of communication but also had definite economic consequences. The rural community could dispossess an unmarried young man of the plot of land that was usually allocated to a male family member. Research suggests that the young community had its own stages of female and male development with the main purpose being to get married. Karelian folk vocabulary fixed this transition to a new status. After matchmaking, the girl was given the 'title' of bride. However, the final farewell to girlhood came at the wedding ceremony. The 'temporary death' symbolised change of identity. During the wedding ritual the bride remained in the suspended state between life and death; she was passive, dressed by others, led by the arm, lamented over (Konkka 1992; Olson and Adonyeva 2016). A young boy was also addressed in a different way. He was named sulhani, sulhoi, ženihhu - 'groom'. Unlike the girl, the young man remained in his family and did not change his kinship. This can explain why wedding rites focused on the groom were less complicated.

\section{CONCLUSIONS}

Karelian folk culture developed its own adolescent age frames. Along with mastering household skills, participation in the youth amusement was a significant stage that marked adolescent transition into a new status, neičyt and priha ('maiden' and 'bachelor', young people who are not yet married). Karelian folk culture can be characterised by its own age framework which differed from the official legislation. At the age of between 13 and 16, young females and males ceased to be called children, they became adolescents, or 'full-age young people'. It should be said that the girls' childhood was somewhat shorter than the boys' as they were introduced to housekeeping and looking after their siblings at an early age. The transition to a new status is reflected in the folk lexis, clothes, specific youth communication forms and behavioural patterns. 
Young female and male leisure time consisted of participation in traditional rural festivities, and in youth gatherings connected to their transitional status. Leisure structure included joint pastime and get-togethers separate for girls and boys. In the autumn and winter, besyodas, get-togethers, were commonly organised indoors, while the summer and spring period was associated with outdoor amusement and games. This was the period when young people were released from household and fieldwork.

The youth behaviour rules during gatherings and besyodas depended on a set of factors, i.e. the time of the gathering, as well as regional and religious traditions. There were also distinct gender related variations between Karelian female and male youth. This research revealed that boys tried to show their courage, boldness and physical strength, while girls were more active in games and dance. At the same time, girls had to remember that they should protect their honour and dignity, qualities indispensable to the reputation of the Karelian peasant family. In other words, the young Karelian girl had to strike a balance between social prohibitions and active play, between modesty and liberated behaviour.

The choice of behavioural patterns adopted in rural society and the observation of these patterns were considered symbolic youth capital, i.e. the reputation of a girl or boy both in the youth community and in the wider rural community of the village. In contrast, refusal to participate in the traditional action algorithm, i.e. marriage, assumed the imposition of certain sanctions by the rural society because a young man or a girl had not yet completed their transition to the status of married man (muzhik) or married woman $(b a b a)$.

\section{Abbreviations}

K.p. - Karelian Proper dialect

Livv. - Livvi dialect of the Karelian language

Lud. - Ludic dialect of the Karelian language

\section{NOTES}

1 A genre of the Karelian folklore, musical and poetic solo improvisation.

2 Pancake week/Shrovetide, an ancient Slavic holiday celebrated during the week before Lent. In the folk calendar of eastern Slavic and neighbouring peoples it is marked as the end of winter and the beginning of spring.

3 Testing the housekeeping skills was organised during the matchmaking ceremony: the matchmakers (svaty) tried to distract a young peasant girl's attention when she was making dishes for guests by interrupting her and interfering in the process of cooking.

4 A set of religious movements in the Russian Orthodox Church that rejected the church reform undertaken between the 1650s and 1660s.

\section{SOURCES}

SA KarRC - Scientific Archive of Karelian Research Centre of the Russian Academy of Sciences [НА КарНЦ- Научный архив Карельского научного центра Российской академии наук]: 
Fond 1, collection 5, file 265 - Field notes of A. K. Gulyashevoy. Examples of Karelian speech (livvi dialect). Village of Megrega, Olonetskiy rayon (Description of Karelian wedding), 1964. [Фонд 1, коллекция 5, дело 265 - Полевая тетрадь А. К. Гуляшевой. Образцы карельской речи (ливвиковский диалект). д. Мегрега Олонецкого района (Описание карельской свадьбы), 1964.]

Fond 1, inventory 50, file 1 - Field notes no. 1 of Yu. Yu. Surkhasko. Materials of expeditions. Medvezh'egorskiy, Muyezerskiy, Pryazhinskiy, Prionezhskiy, Kondopozhskiy, Olonetskiy rayons of the Republic of Karelia, 1964-1972. [Фонд 1, опись 50, дело 1 - Полевая тетрадь № 1 Ю. Ю. Сурхаско. Материалы экспедиции. Медвежьегорский, Муезерский, Пряжинский, Прионежский, Кондопожский, Олонецкий районы Республики Карелия, 1964-1972.]

Fond 1, inventory 50, file 3 - Field notes no. 2 of Yu. Yu. Surkhasko. Materials of expeditions. Medvezh'egorskiy, Muyezerskiy, Pryazhinskiy, Prionezhskiy, Kondopozhskiy, Olonetskiy rayons of the Republic of Karelia, 1965-1970. [Фонд 1, опись 50, дело 3 - Полевая тетрадь № 2 Ю. Ю. Сурхаско. Материалы экспедиции. Медвежьегорский, Муезерский, Пряжинский, Прионежский, Кондопожский, Олонецкий районы Республики Карелия, 1965-1970.]

Fond 1, inventory 50, file 4 - Field notes no. 3 of Yu. Yu. Surkhasko. Materials of expeditions. Medvezh'egorskiy, Muyezerskiy, Pryazhinskiy, Prionezhskiy, Kondopozhskiy, Olonetskiy rayons of the Republic of Karelia, 1965-1970. [Фонд 1, опись 50, дело 4 - Полевая тетрадь 3 Ю.Ю. Сурхаско. Материалы экспедиции. Медвежьегорский, Муезерский, Пряжинский, Прионежский, Кондопожский, Олонецкий районы Республики Карелия, 1965-1970.]

Fond 1, inventory 50, file 5 - Field notes of Yu. Yu. Surkhasko. Materials of expeditions. Loukhskiy and Kondopozhskiy rayons of the Republic of Karelia, 1974 [Фонд 1, опись 50, дело 5 - Полевые записи Ю.Ю. Сурхаско. Материады экспедиции. Аоухский и Кондопожский районы Республики Карелия, 1974.]

\section{REFERENCES}

Abu-Lughod, Lila. 1991. Writing against Culture. - Recapturing Anthropology: Working in the Present, edited by Richard Fox. Santa Fe, NM: School of American Research Press, 137-162.

Apo, Satu. 1998. "Ex cunno Come the Folk and Force": Concepts of Women's Dynamistic Force in Finnish-Karelian Tradition. - Gender and Folklore: Perspectives on Finnish and Karelian Culture. Studia Fennica Folkloristica 1, edited by Satu Apo, Aili Nenola and Laura Stark-Arola. Helsinki: Finnish Literature Society, 63-91.

Bayburin, Albert Kashfullovich. 1993. Ritual v traditsionnoy kul'ture. Strukturno-semanticheskiy analiz vostochnoslavyanskikh obryadov. Sankt-Peterburg: Nauka. [Байбурин, Альберт Кашфулиович. 1993. Ритуал в традиционной культуре. Структурно-семантический анализ восточнославянских обрядов. Санкт-Петербург: Наука.]

Bernshtam, Tatyana Aleksandrovna. 1988. Molodezh'v obryadovoy zhizni russkoy obshchiny kontsa XIX - nachala XX veka. Polovozrastnoy aspekt traditsionnoy kul'tury. Leningrad: Nauka. [Бернштам, Татьяна Александровна. 1988. Молодежь в обрядовой жизни русской общцинь концุа XIX - начала XX века. Половозрастной аспект традициионной культуры. Денинград: Наука.]

Blagoveshchenskiy, Ivan. 1878. Posidelki v okrestnostyakh goroda Olontsa. - Olonetskiye gubernskiye vedomosti 94: 1135. http://ogv.karelia.ru/magpage.shtml?id=4172\&page=9 (accessed July 14, 2016). [Благовещенский, Иван. 1878. Посиделки в окрестностях города Олонца. - Олонецькие губернские ведомости 94: 1135. http://ogv.karelia.ru/magpage.shtml?id=4172\&page=9] 
Bogdanov, Grigoriy Khristoforovich. 1930. Svad'ba v Ukhtinskoy Karelii. - Zapadnofinskiy sbornik, edited by Vasiliy Bartol'd. Leningrad: Izdatel'stvo Akademii Nauk SSSR, 36-65. [Богданов, Григорий Христофорович. 1930. Свадьба в Ухтинской Карелии. - Западнофинский сборник, отв. ред. Василий Бартольд. Аенинград: Издательство Академии Наук СССР, 36-65.]

Chernyakova, Irina Aleksandrovna. 2003. Brachnoye povedeniye v Olonetskoy, Belomorskoy i Tverskoy Karelii v XVIII i XIX vv. - Väesto ja perhe Karjalassa. Naseleniye Karelii i karel'skaya sem'ya, edited by Yuriy Shikalov, Tapio Hämynen, Jukka Partanen. Joensuu: Joensuun yliopisto, 133-143. [Чернякова, Ирина Александровна. 2003. Брачное поведение в Олонецкой, Беломорской и Тверской Карелии в XVIII и XIX вв. - Väesto ja perhe Karjalassa. Haceлeние Карелии и карельская семья, отв. ред. Юрий Шикалов, Тапио Хянюнен, Юкка Партанен. Joensuu: Университет Йоэнсуу, 133-143.]

Fedotova, Vieno Petrovna. 2000. Frazeologicheskiy slovar' karel'skogo yazyka. Petrozavodsk: Periodika. [Федотова, Виэно Петровна. 2000. Фразеологический словарь карельского языка. Петрозаводск: Периодика.]

Georgiyevskiy, Mikhail. 1888. Etnograficheskiye zametki. Svyatozero. - Olonetskiye gubernskiye vedomosti 18: 163-166. http://ogv.karelia.ru/magview.shtml?id=772\&page=5 (accessed July 17, 2016). [Георгиевский, Михаил. 1888. Этнографические заметки. Святозеро. - Олонец̧кие губернские ведомости 18: 163-166. http://ogv.karelia.ru/magview.shtml?id=772\&page=5]

Georgiyevskiy, Mikhail. 1890. Iz narodnoy zhizny. - Olonetskiye gubernskiye vedomosti 72: 733-743. [Георгиевский, Михаил. 1890. Из народной жизни. - Олонецккие губернские ведомости 72: 733-743.]

Hämynen, Tapio. 1993. Liikkeellä leivän tähden: Raja-Karjalan väestö ja sen toimeentulo 1880-1940. Helsinki: Suomalaisen Kirjallisuuden Seura.

Ilyukha, Olga Pavlovna. 2007. Shkola i detstvo v karel'skoy derevne v kontse XIX - nachale XX veka. Sankt-Peterburg: Dmitriy Bulanin. [Илюха, Ольга Павловна. 2007. Школа и детство в карельской деревне в конце XIX - начале XX века. Санкт-Петербург: Дмитрий Буланин.] Inha, Into Konrad. 1911. Kalevalan laulumailta. Helsinki: Juminkeko-säätiö.

Ivanova, Lyudmila Ivanovna and Valentina Petrovna Mironova. 2014. Kuldazet kukkizet da kaunehet kanazet. Magiya podnyatya lembi i svad'ba v karel'skoy narodnoy kul'ture: issledovaniya i materialy. Kukhmo: Yuminkeko. [Иванова, Людмила Ивановна и Валентина Петровна Миронова. 2014. Kuldazet kukkizet da kaunehet kanazet. Магия поднятия лемби и свадьба в карельской народной культуре: исследования и материаль. Кухмо: Юминкеко.]

Joki, Leena and Katariina Jeskanen, comp. 1993. Karjalan kielen sanakirja. Osa 4, O-P, edited by Raija Koponen. Helsinki: Suomalaisen Kirjallisuuden Kirjapaino OY.

Kantorovich, Yakov Abramovich, comp. 1899. Zakony o detyakh. Sankt-Peterburg: Izdaniye Ya. Kantorovicha. [Канторович, Яков Абрамович, сост. 1899. Законы о детях. Санкт-Петербург: Издание Я. Канторовича.]

Keinänen, Liisa-Marja. 2003. Creating Bodies: Childbirth Practices in Pre-Modern Karelia. Stockholm: Stockholm University.

Konkka, Aleksey Petrovich. 2015. Na plechakh Bol'shoy Medveditsy. Izbrannyye stat'i. Petrozavodsk: Karel'skiy nauchnyy tsentr RAN. [Конкка, Алексей Петрович. 2015. На плечах Большой Медведиць. Избранные статьи. Петрозаводск: Карельский научный центр РАН.]

Konkka, Unelma Semenovna and Aleksey Petrovich Konkka. 1980. Dukhovnaya kul'tura Segozerskikh karel kontsa XIX - nachala XX v., edited by Yevgeniy Ivanovich Klement'ev. Leningrad: Nauka. [Конкка, Унелма Семеновна и Алексей Петрович Конкка. 1980. Духовная культура Сегозерских карел кониза XIX - начала XX в., отв. ред. Евгений Иванович Клементьев. Ленинград: Наука.]

Konkka, Unelma Semenovna. 1992. Poeziya pechali: karel'skiye obryadovye plachi. Petrozavodsk: Karel'skiy nauchnyy tsentr RAN [Конкка, Унелма Семеновна. 1992. Поэзия печали: карельские обрядовые плачи. Петрозаводск: Карельский научный центр РАН.] 
Koponen, Raija; Marja Lehtinen and Laila Rissanen, comp. 1983. Karjalan kielen sanakirja. Osa 3, $L-N$, edited by Pertti Virtaranta. Helsinki: Suomalais-ugrilainen Seura.

Krinichnaya, Neonila Artemovna. 2014. Mifologiya vody i vodoyemov: bylichki, byval'shchiny, pover'ya $i$ etiologicheskiye rasskazy Russkogo Severa. Petrozavodsk: Karel'skiy nauchnyy tsentr RAN. [Криничная, Неонила Артемовна. 2014. Мифология воды и водоемов: былички, бывальщины, поверья и этиологические рассказы Русского Севера. Петрозаводск: Карельский научный центр РАН.]

Lavonen, Nina Aleksandrovna; Aleksandra Aleksandrovna Stepanova and Karl Rautio, comp. 1993. Karel'skiye yëygi. Petrozavodsk: Karel'skiy nauchnyy tsentr RAN. [Лавонен, Нина Александровна; Александра Александровна Степанова и Карл Раутио, сост. 1993. Карельские ёйги. Петрозаводск: Карельский научный центр РАН.]

Litvin, Yuliya Valeryevna. 2013. Povsednevnaya zhizn' karel'skoy krest'yanki vo vtoroy polovine XIX - nachale XX veka: sotsiokul'turnyy status i gendernyye roli. Petrozavodsk: Karel'skiy nauchnyy tsentr RAN. [Питвин, Юлия Валерьевна. 2013. Повседневная жизнь карельской крестьянки во второй половине XIX - начале XX века: соичикультурный статус и гендерные роли. Петрозаводск: Карельский научный центр РАН.]

Lukkarinen, Jussi. 1933. Suomalaisten naimatapoja: aineksia suomalaisten kansojen avioliiton historiaan. Suomalaisen Kirjallisuuden Seuran Toimituksia 186, Kansatieteellisiä kuvauksia IV. Helsinki: Suomalaisten Kirjallisuuden Seura.

Makarov, Grigoriy Nikolayevich, comp. 1990. Slovar' karel'skogo yazyka (livvikovskiy dialekt). Petrozavodsk: Kareliya. [Макаров, Григорий Николаевич, сост. 1990. Словарь карельского языка (ливвиковский диалект). Петрозаводск: Карелия.]

Miettinen, Liisa and Pentti Leino, comp. 1971. Karjalaisia sananpolvia. Helsinki: Forssan Kirjanpaino OY.

Minorskiy, Petr. 1879. Olonetskiye karely i Il'inskiy prikhod Olonetskogo uyezda. - Olonetskiye gubernskiye vedomosti 61: 731-732. http://ogv.karelia.ru/magpage.shtml?id=3223\&page=10 (accessed August 13, 2016). [Минорский, Петр. 1879. Олонецкие карелы и Ильинский приход Олонецкого уезда. - Олонецкие губернские ведомости 61: 731-732. http://ogv.karelia.ru/magpage.shtml?id=3223\&page=10]

Nikolskiy, Ivan. 1906. Derevnya Prokkoila i narodnoye obrazovaniye v ney. - Olonetskiye gubernskiye vedomosti 120: 3 [Никольский, Иван. 1906. Деревня Проккойла и народное образование в ней. - Олонецкие губернские ведомости 120: 3.]

Olson, Lora and Svetlana Adonyeva. 2016. Traditsiya, transgressiya, kompromiss. Miry russkoy derevenskoy zhenshchiny. Moskva: Novoye literaturnoye obozreniye. [Олсон, Лора и Светлана Адоньева. 2016. Традиция, трансгрессия, компромисс. Миры русской деревенской женщины. Москва: Новое литературное обозрение.]

Prokopyeva, Natalya. 2005. Kholostyak. - Muzhiki i baby. Muzhskoye i zhenskoye v russkoy traditsionnoy kul'ture. Illyustrirovannaya entsiklopediya, edited by Izabella Iosifovna Shangina. SanktPeterburg: Iskusstvo-SPB, 668-670. [Прокопьева, Наталья. 2005. Холостяк. - Мужики и бабьл. Мужское и женское в русской традиционой культуре. Иллюстрированная әнциклопедия, науч. ред. Изабелла Иосифовна Шангина. Санкт-Петербург: Искусство-СПБ, 668-670.]

Pushkareva, Natalya L'vovna. 2003. Gendernaya asimmetriya sotsializatsii rebenka v traditsionnoy russkoy sem'ye. - Gendernyye stereotipy $v$ proshlom $i$ nastoyashchem, edited by Irina Mikhaylovna Semashko. Moskva: Institut ehtnologii i antropologii RAN, 4-25. [Пушкарева, Наталья Львовна. 2003. Гендерная асимметрия социализации ребенка в традиционной русской семье. - Гендерные стереотипь в прошлом и настоящем, отв. ред. Ирина Михайловна Семашко. Москва: Институт этнологии и антропологии РАН, 4-25.]

Sarmela, Matti. 1989. Suomen perinneatlas. Helsinki: Suomalaisten Kirjallisuuden Seura.

Shchepanskaya, Tatyana Borisovna and Izabella Iosifovna Shangina. 2005. Pol i narodnaya kul'tura. - Muzhiki i baby. Muzhskoye i zhenskoye v russkoy traditsionnoy kul'ture. Illyustrirovan- 
naya entsiklopediya, edited by Izabella Iosifovna Shangina. Sankt-Peterburg: Iskusstvo-SPB, 6-16. [Щепанская, Татьяна Борисовна и Изабелла Иосифовна Шангина. 2005. Пол и народная культура. - Мужики и бабы. Мужское и женское в русской традиционной культуре. Иллюстрированная энцииклопедия, науч. ред. Изабелла Иосифовна Шангина. Санкт-Петербург: Искусство-СПБ, 6-16.]

Shikalov, Yury. 2010. "Ilona on käki metsässä, ilona on lapsi perheessä". Syntymä, imeväiskuolleisuus ja aviottomat lapset Vienan Karjalassa ja Vienanmeren länsirannikolla 1860-1910-luvuilla. Helsinki: Suomalaisten Kirjallisuuden Seura.

Shikalov, Yuriy. 2013. "Podol'she v devushkakh pokhodish', pomen'she zamuzhem pozhivesh": reproduktivnyy period i brachnyy vozrast zhenskogo naseleniya Belomorskoy Karelii v kontse XIX - nachale XX v. - Karel'skaya sem'ya vo vtoroy polovine XIX - nachale XXI v.: etnokul'turnaya traditsiya $v$ kontekste sotsialnykh transformatsiy. Sbornik statey i materialov, edited by Olga Pavlovna Ilyukha. Petrozavodsk: Karel'skiy nauchnyy tsentr RAN, 89-110. [Шикалов, Юрий. 2013. “Подольше в девушках походишь, поменьше замужем поживешь": репродуктивный период и брачный возраст женского населения Беломорской Каредии в конце XIX - начале XX в. - Карельская семья во второй половине XIX - начале XXI в.: этнокультурная традиция в контексте социильных трансформаций. Сборник статей и материалов, отв. ред. Ольга Павловна Илюха. Петрозаводск: Карельский научный центр $\mathrm{PAH}, 89-110$.

Sinitskaya, Natalya Anatolyevna; Yelena Viktorovna Filippova and Galina Yegorovna Lettiyeva, eds. 2007. Karel'skiye poslovitsy i pogovorki. Karjalazet sananlaskut da sananpiät. Petrozavodsk: Periodika. [Синицкая, Наталья Анатольевна; Елена Викторовна Филиппова и Галина Егоровна Леттиева, ред. 2007. Карельские пословицы и поговорки. Karjalazet sananlaskut da sananpiät Петрозаводск: Периодика.]

Smirnova, Svetlana Sergeyevna. 2002. Demograficheskiye protsessy v Olonetskoy gubernii v XIX - nachale XX vv. Opyt komp'yuternogo analiza metricheskikh knig. Dissertatsiya kandidata istoricheskikh nayk. Sankt-Peterburgskiy gosudarstvennyy universitet. http://search.rsl. ru/ru/record/01002321223 (accessed December 23, 2016). [Смирнова, Светлана Сергеевна. 2002. Демографические процессы в Олонецкой губернии в XIX - начале XX вв. Опыт компьютерного анализа метрических книг. Диссертация кандидата исторических наук. Санкт-Петербургский государственный университет.]

Stark, Laura. 1998. Magic, Body and Social Order: The Construction of Gender Through Women's Private Rituals in Traditional Finland. Studia Fennica Folkloristica 5. Helsinki: Finnish Literature Society.

Stepanova, Aleksandra Aleksandrovna. 2004. Tolkovyy slovar' yazyka karel'skikh prichitaniy. Petrozavodsk: Periodika. [Степанова, Александра Александровна. 2002. Толковый словарь языка карельских причитаний. Петрозаводск: Периодика.]

Surkhasko, Yugo Yulyevich. 1977. Karel'skaya svadebnaya obryadnost' (konets XIX - nachalo XX v.). Leningrad: Nauka. [Сурхаско, Юго Юльевич. 1977. Карельская свадебная обрядность (конеи, XIX - начало XX в.). Ленинград: Наука.]

Vinokurova, Irina Yuryevna. 1994. Deti v nekotorykh obriadakh i predstavleniyakh vepsov. Obryady i verovaniya narodov Karelii. Chelovek i ego zhiznennyy tsikl, edited by Yugo Yul'yevich Surkhasko and Irina Yur'yevna Vinokurova. Petrozavodsk: Karel'skiy nauchnyy tsentr RAN, 41-64. [Винокурова, Ирина Юрьевна. 1994. Дети в некоторых обрядах и представлениях вепсов. - Обряды и верования народов Карелии. Человек и его жизненный изикл, науч. ред. Юго Юльевич Сурхаско и Ирина Юрьевна Винокурова. Петрозаводск: Карельский научный центр РАН, 41-64.]

Virtaranta, Pertti. 1958. Vienan kansa muistelee. Porvoo: Werner Osakeyhtiön kirjaanpaino.

Virtaranta, Pertti. 1964. Lyydiläisiä teksteja III. Helsinki: Suomalaisten Kirjallisuuden Seura. 